\title{
DEVELOPMENT AND REGULATORY SYSTEM REFORM OF TELECOMMUNICATION INDUSTRY IN CHINA
}

\author{
LIANG Xiongjian, ZHANG Wei, and ZHANG Xueyuan \\ College of Management \& Humanities \\ Beijing University of Posts \& Telecommunications, P.O.Box 164 \\ 10 Xi Tucheng Road, Beijing, China, 100876 \\ E-mail: liangxj@bupt.edu.cn, b9400013@bupt.edu.cn
}

\begin{abstract}
The paper reviews achievements and history of telecommunications development and regulatory system reform in China, discusses the evolution of reform, analyses influence of regulatory system reform to China's telecommunication industry, and finally makes some suggestions on the development of China Telecom.
\end{abstract}

Keywords: Telecommunication, Development, Regulatory System, China

\section{DEVELOPMENT OF TELECOMMUNICATION IN CHINA}

\subsection{Achievements}

China has got significant achievement in telecommunications over last about 50 years. In 1998, the switching capacity of the central office exchanges reached 135 million main lines. Some 17.04 million new telephone subscribers got access to the PSTN network, so that telephone subscribers in the whole country totaled 87.35 million. Mobile subscribers got to some 23.56 million, increased by 10.33 million over the year 1997 . The telephone density of the whole country was raised to $10.53 \%$, and that for the urban areas to $27.7 \%$. The growth curve of the telephone density of the whole country, shown in Fig.1, can be used to indicate the development of telecommunications in China. From Fig.1, it is found that telecommunications in China has been developing very quickly since 1990 .

The developing curve of total turnover of telecommunications services is shown in Fig.2. The total turnover of telecommunications reached 188.89 billion RMB in 1998, increasing by 17 times more than 10.95 billion RMB in 1990. The total turnover of telecommunications has been developing in an exponential curve.

Table 1 shows the development of some telecommunications services 
and capacity in China. It is also found that subscribers of telecommunications services and telecommunications capacity have been increasing with a high rate since 1990. At the same time, with the development of traditional services and the enlarging of the network size, many new value-added services, such as E-mail, facsimile store and forward, and Internet service, are introduced to subscribers. These new services are welcomed by subscribers and also get a high growth rate. Table 2 shows the development of new services during these years. Since 1994, most of new data services have been developing at the growth rate of over $100 \%$. Especially, Internet subscribers have been increasing at the annual rate of $377.8 \%$ since 1995. It makes the telecommunications service market developing in a diversified way.

\subsection{Review}

In the early days after the People's Republic of China was just set up in 1949, it only held the capacity of switch system with over 310 thousand lines, and 208,750 telephones subscribers. The telephone density is only $0.05 \%$. So Telecommunications, as a foundational industry, was very unstable at that time. But from 1949 to 1977, telecommunications developed very slowly in China because the role of telecommunications in national economy couldn't be recognized correctly. By the end of 1977, the telephone density was only $0.36 \%$, increasing less $0.02 \%$ every year.

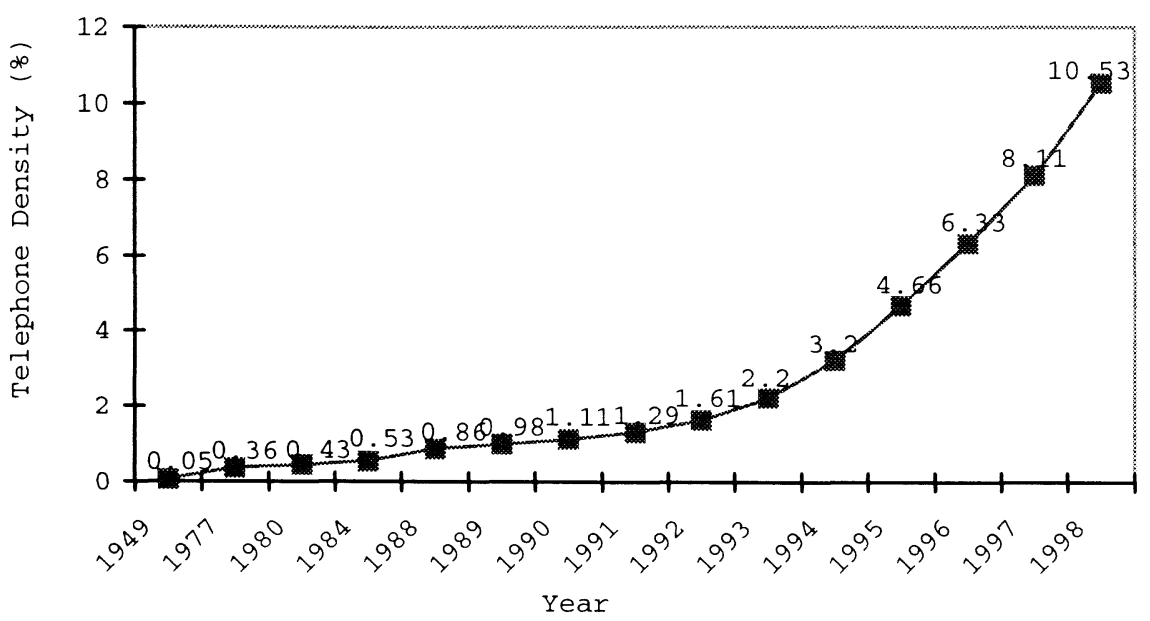

Fig.1. The Development of Telephone Density in China 
(In Billion RMB)

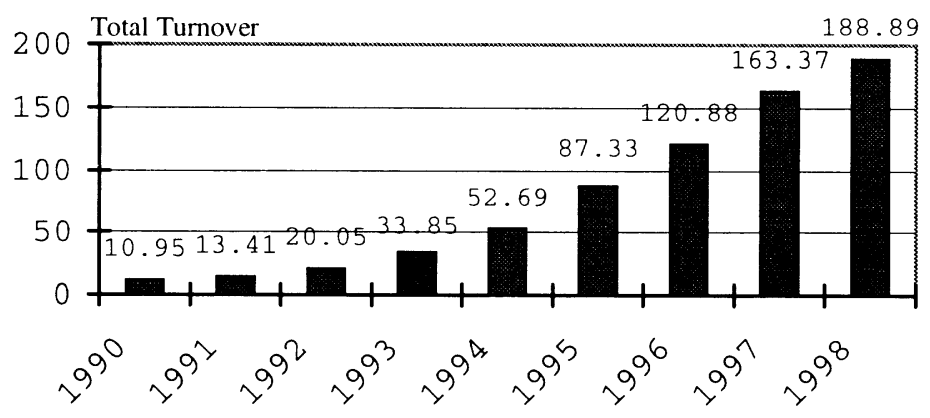

year

Fig.2. Developing Trend of Total Turnover of Telecommunications in China

Table 1. The Development of Telecommunications Services and Capacity

\begin{tabular}{|l|l|l|l|l|l|l|l|l|l|}
\hline & unit & 1978 & 1984 & 1989 & 1990 & 1995 & 1996 & 1997 & 1998 \\
\hline $\begin{array}{l}\text { Long-distance } \\
\text { Circuits }\end{array}$ & million & 0.019 & 0.032 & 0.087 & 0.1124 & 0.865 & 1.04 & 1.24 & 1.74 \\
\hline $\begin{array}{l}\text { Automatic Toll } \\
\text { Switching } \\
\text { Capacity }\end{array}$ & million & 0.0019 & 0.0065 & 0.103 & 0.161 & 3.408 & 4.26 & 4.45 & 4.82 \\
\hline $\begin{array}{l}\text { Central Office } \\
\text { Exchanges }\end{array}$ & million & 4.06 & 5.54 & 10.35 & 12.01 & 70.96 & 93.18 & 110.9 & 134.9 \\
\hline $\begin{array}{l}\text { Telephone } \\
\text { Subscribers }\end{array}$ & million & 1.93 & 2.77 & 5.68 & 6.85 & 40.71 & 54.95 & 70.27 & 87.35 \\
\hline $\begin{array}{l}\text { Mobile } \\
\text { Subscribes }\end{array}$ & million & - & - & - & 0.0183 & 3.63 & 6.85 & 13.23 & 23.56 \\
\hline $\begin{array}{l}\text { Paging } \\
\text { Subscriber }\end{array}$ & million & - & - & 0.237 & 0.437 & 17.43 & 25.41 & 34.19 & 37.83 \\
\hline
\end{tabular}

Since the beginning of reform and opening in China, the significance of telecommunications was recognized gradually. The state government brought forward some policies, such as first-installation fee of telephone, in order to support the development of telecommunications. It was very important to the development of telecommunications afterwards. As a whole, 
since the reform and opening, the development of telecommunications has undergone three periods in China.

Table 2. The Development of New Value-added Services

\begin{tabular}{|c|c|c|c|c|c|c|}
\hline & Unit & 1994 & 1995 & 1996 & 1997 & 1998 \\
\hline Packet switching subscribers & thousand & 8.5 & 28 & 56.4 & 84.6 & 106 \\
\hline DDN subscribers & thousand & - & 17 & 51.4 & 111.7 & 189 \\
\hline Videotext subscribers & thousand & 1.083 & 2.495 & 1.987 & 2.247 & 1.7 \\
\hline EDI subscribers & thousand & - & 0.132 & 0.113 & 0.216 & 0.403 \\
\hline $\begin{array}{l}\text { Facsimile storage transfer } \\
\text { subscribers }\end{array}$ & thousand & - & 0.495 & 1.217 & 2.914 & 5.258 \\
\hline $\begin{array}{l}\text { Internet } \\
(\mathrm{ChinaNet})\end{array}$ & thousand & - & 7.000 & 34.000 & 159.803 & 680 \\
\hline Frame relay subscribers & & - & - & - & 3084 & 8221 \\
\hline $\mathrm{N}$-ISDN subscribers & thousand & - & - & - & 0.319 & 25.533 \\
\hline
\end{tabular}

The first period was from 1978 to 1984. In order to meet the needs of economic development, the State Council offered some special policies on telecommunications field, such as low tax, etc. The Ministry of Posts and Telecommunications (MPT) decided to transfer its first priority to the modernization of telecommunications so that telecommunications better served the modernization of Chinese economy. It ended the long-period slow development of telecommunications in China. During this period, the development of telecommunications insisted on some principles, the unitive control of MPT and specialization development and so on. The first priority problem to deal with was to release the pressure of telephone capacity shortage in big cities. Since then, MPT has begun to charge the firstinstallation fee of telephone. At the same time, MPT began to actively introduce into foreign fund, modern technologies and management methods to drive the development of telecommunications. In 1982, the first SPC in China was introduced into and installed in Fuzhou, which indicated the beginning of new period of telecommunications.

The second period was from 1984 to 1989 . In this period, Chinese economy was rapidly growing. With deepening of reform and opening process and development of national economy, the demands for telecommunications was increasing speedily, which posed great strike on telecommunications of China. The significance of telecommunications was 
becoming obvious. Telecommunications was recognized as strategic pivot of national economy, and developed preferentially under some favorable policies approved by the State Council. In addition, local governments also supported its development greatly. All of these accelerated the development of telecommunications. It signed the beginning of high-speed takeoff of telecommunications in China.

The third period was from 1989 to now. In this period, telecommunications in China has been developing with great speed. The size of telecommunications network has been quickly enlarged year by year, with advanced technologies. The capacity of telecommunications network has been increasing. Since 1989, MPT has emphasized researches on management, which became urgent to the modernized telecommunications network. MPT began to adjust the network structure, and organized training program to administrative personnel in order to make them prepare in mind and work method for the transition from the manual network to the automated network. Up to 1998, telecommunications network of China has developed into the second largest telecommunications network in size in the world. With the development of network, the management of network began to step into a new period.

\section{EVOLUTION OF REGULATORY SYSTEM REFORM OF CHINA'S TELECOMMUNICATION INDUSTRY}

Telecommunication industry has been keeping high-speed development for the recent years in China. In this process, customer's demand is increasing, telecommunication technologies are in progress, and telecommunication market is becoming more and more open. All of these changes require adaptive regulatory system. Under the old system, the Ministry of Posts and Telecommunications (MPT) has both government and corporate functions, which results in nonstandard market behaviors and unfair competition. All of this malpractice is hampering the development of telecommunication industry in China. Therefore, it is very urgent to reform the old system.

In 1998, after a long period of argumentation and gestation, China took a key step and made great achievement in the regulatory system reform of telecommunications industry.

Firstly, with the reform of government organization, the Ministry of Information Industry (MII), newly founded on the base of the MPT and the Ministry of Electronic Industry, replaced the former MPT to manage the information industry. The functions of new MII are set as follows: to rebound manufacture of electric information production, communications and software industry to boost the informatization of national economy and 
social services; to set industry plan, policies and rules; to make overall plans of national communications backbone networks (including local and longdistance telecommunication network), broadcasting and television networks and other private communications networks; to rationally collocate all resource to avoid the reduplicate construction; to guarantee the information safety.

In this definition, we can observe that the new system has some features, different from the old one, as follows:

- The means of management is different. The new MII will control the information industry mainly by industry plans, policies and rules.

- The range of management is different. The range of management of MII will cover manufacture of electric information production, communications and software industry, exceeding the management range of former MPT.

However, the above changes will be realized only on the base of the divergence between government and enterprise functions.

Secondly, the divergence between government and enterprise functions will be really realized under the new regulatory system. Comparing with the functions of MPT ratified by the state council in 1994, we can find that the MII no longer has the function of managing and operating the national public communications network. It shows that the government organization reform will be helpful to realize the divergence of government and enterprise functions. Consequently, a variety of malpractice, such as indefinite property right relation, low interior efficiency and unresponsiveness to market needs, as a result of integration of government and enterprise functions, will be solved gradually.

China Telecom, after the divergence of government and enterprise functions and the separation from posts operation, will become a real corporate with self-operating and self-assuming sole responsibility for its profits or loss. It then can engage in market competition independently. In China, some value-added services have been opened to domestic operators since 1993. Especially in 1994, China Unicom entered into the telecommunications service market and obtained the license of operating the basic telecommunications services. Competition has been spreading in all areas of telecommunications service market in China, and will be more intense.

Thirdly, telecommunication operation will gradually separate from posts operation. In China, telecommunications and posts have been co-operated under MPT for a long period, so telecommunications always provided crosscompensation for posts in order to maintain the development of posts. Telecommunications is a technology-, capital- and brain-dense industry. With the development of telecommunication technologies, there are more and more differences in marketing, operating and management between 
telecommunications and posts. The old co-operation system begins to tie down the development of telecommunications. What's more, telecommunications enterprises have no their independent economic counting under the old system, which goes against the establishment of a fair, open, normative and ordered market environment. It means that the old co-operation system must be changed.

Currently, the divergence of telecommunications and posts operation is going on pressingly. It is expected to finish by the end of the year 1999 .

\section{A HISTORICAL REVIEW OF CHINA'S TELECOMMUNICATION REGULATORY SYSTEM REFORM}

As an important sector of the national economy, the telecommunication industry was controlled by the government in the last 45 years. On the other hand, due to its unique characteristics of networking and cooperating, the telecommunication industry has to be planned, constructed and operated as a whole to realize large-scale benefits. These reasons caused the monopoly of China's telecommunication industry. The former Ministry of Posts and Telecommunications represented the government authorities for regulating the telecommunication industry and, at the same time, operated a national public telecommunication network and provided telecommunication services just as an enterprise did.

After China began the reform and openness process, the functions of MPT had changed and adjusted twice, which occurred in 1988 and 1994 respectively.

In 1988, the main functions of MPT were as following:

- to set the policies, rules, systems, plan and reform approach of the telecommunication industry and to supervise the performance;

- to regulate the domestic and international postal and telecommunication, to join the international communication organizations representing China and to deal with other issues concerning China's communication industry; to manage the national telecommunication standards and sequence, to coordinate private networks of different departments;

- to manage directly the telecommunication enterprises of the whole nation and to provide telecommunication services.

At that time the regulatory system combining the government and enterprises functions was a result of the country's planning economy. The advantages of this system was that it could collect resources from the whole country so as to be able to plan and build some huge projects and get the large-scale benefits. It had contributed greatly for the development of China's telecommunication industry.

In 1990's, China's economic reform entered a new phase and the 
telecommunication industry also saw some new changes. From 1993 on, with the approval of the State Council, some selected telecommunication services had been opened to the market. In 1994, China Unicom was founded as the second telecommunication provider in China. The monopoly of China Telecom was broken and competition was firstly introduced into the telecommunication industry.

Under this new circumstance, the State Council approved a new plan in 1994, which defined the functions of MPT. This plan summarized the functions of MPT into three categories:

- to macro-control the national telecommunication industry and carry on the planning, coordinating, serving and surprising responsibilities.

- to manage the national public telecommunication network, to ensure the unity, integrity and advance of the network and to regulate the national telecommunication market.

- to safeguard state benefits and to protect the customer's rights.

The 1994 plan made it clear that MPT was a government department responsible for the telecommunication regulation. This helped to set up the basis for the future divergence of government and enterprise functions. However, due to reasons that the national economic reform is not thorough, the market regulation is not perfect, the legal system is not strengthened and the overall social reform is not ready, the regulatory system reform of China's telecommunication industry had not progressed substantially.

\section{INFLUENCE OF REGULATORY SYSTEM REFORM TO CHINA'S TELECOMMUNICATION INDUSTRY}

It is no doubt that the system reform of China's telecommunication regulation in 1998 will have a significant effect. As a market with the biggest potential in the world, China is expecting to establish an united and efficient telecommunication regulatory body with coordinated operation, to ensure a fair, standardized and orderly market environment for competition and to set up telecommunication enterprises according with the demand of modern market economy. By these means, the telecommunication industry will become a new growth point of the national economy and find its position in the international market.

Generally speaking, the regulatory system reform has such influences as follow:

- The divergence between government and enterprise functions will guarantee that the fair competition of telecommunication market is standardized. 
Under the conventional system, enterprises competing in the telecommunication market belonged to various government departments respectively. Because the benefits of these various departments were different, the enterprises tended to compete unstandardizedly. That is to say, some government departments would help their own enterprises by misusing their authorities. Therefore, the competition was difficult to be unified and fair. One of the purposes of the reform is to set up a market place of fair competition. With this market place, enterprises have to focus their attention on products, quality, price and services to satisfy their customers in order to survive and develop themselves, hence the competition of these enterprises will be promoted. On the other hand, the fierce competition will eliminate enterprises that did not perform well and then optimize the distribution of resources. This will improve the usage of resources and bring China's telecommunication industry with vitality and vigor in the forth coming 21century.

- MII will regulate the manufacturing industry of electronics information equipment, telecommunication industry, and software industry as well as manage national public telecommunication networks, broadcasting and television networks, and various private telecommunication networks. It complies with the international trend of convergence of information services and gives much more opportunities for China's information industry in its future development.

It is widely known that, since early 1990's, due to the rapid development of technologies within the fields of computer, telecommunication and multimedia, the trend of convergence of various information services has been more and more obvious. In some countries with highly developed information technologies, such as the USA, the government has gradually removed the barriers for enterprises to enter difference services market and set up legal framework to guarantee it with the purpose of promoting the rapid development of information industry.

From the enterprises' point of view, because enterprises which traditionally operated in different industries, for example, telecommunication industry and television industry, are now becoming potential rivals, so the competition will be more fierce both in depth and in extension. However this will also broaden the enterprises vision while they work on their strategies of development.

- As a result of the regulatory system reform, it will be much easier to get into the telecommunication market. There will be more enterprises which are interested in the provision of information services joining the competition in telecommunication market. These new comers will challenge the conventional enterprises and the customers will hopefully get more convenient telecommunication services with lower price and better quality. 
- The preparation for the opening of China's telecommunication market.

Resulted from the worldwide globalization trend of economy and the effort which China has made to join the WTO, the opening of China's telecommunication market will be inevitable. But China has not proposed a schedule for its telecommunication market opening, mainly because of some specific problems caused by the characteristics of China's telecommunication development, such as subsidiaries between posts and telecommunication enterprises, the unbalanced development among regional areas, the lack of laws and regulations and the preferential policies given by government to telecommunication enterprises, etc. Necessary actives to solve these problems have not been taken.

However, the regulatory system reform is now providing China an opportunity to solve these problems. By means of establishing new regulatory body, separating government functions from enterprises, dividing posts and telecommunications operation and improving laws and regulations, China will gradually find its way out of the difficulties which have blocked the openness of telecommunication market for a long time and merge the Chinese telecommunication market into the international one.

- Influence of the old system will still exist in a period.

Because China has not issued the telecommunication act, the newly established MII finds itself short of a legal foundation to perform the regulation functions of the industry. In this case, it becomes a critical task for MII to draft and promulgate the telecommunication act. But before the establishment of legal framework, the implementation of industry regulation has to use some administrative commands, just as the way it worked in the past. Meanwhile, the old system combining post and telecommunication will encounter lots of problems during the process of reform, which need the coordination of government authorities. Considering all these matters above, we will not expect the influence of old system can be eliminating in a short time. In fact, it will take a relative long time for the new system to replace the old one radically.

\section{SUGGESTIONS ON THE DEVELOPMENT OF CHINA TELECOM}

Being China's largest telecommunication services provider, China Telecom has enjoyed a growth rate of more than $40 \%$ for the last decade. By the end of 1997, China Telecom has built up the world's No.2 wireline telephone network and No.3 mobile telecommunication network and the number of customers has reached 83.5 million. Of course, the regulatory system reform of China's telecommunication industry will bring a significant impact to China Telecom. In short term, it seems China Telecom might suffer 
from the reform. But if we look at it in the long run, the divergence from government functions and the establishment of modern corporation system will definitely grant China Telecom with remarkable benefits. Here we would like to propose some suggestions for the future development of China Telecom.

- View and take the regulatory system reform of telecommunication industry actively instead of passively. As we just mentioned above, the reform will eventually benefit China Telecom. Think about the opportunities brought by the reform and try to make good use of them.

- China Telecom should convert itself from a product-oriented company to a customer-oriented one. That means China Telecom should pay more attention to the customers' needs, shift its strategies to satisfy the customer and maintain its market share in a competitive environment.

- Taking the opportunity of system reform, China Telecom could restructure its organization. By cutting down some nonproductive departments, adjusting services related departments and setting up some new marketing and customer care departments, China Telecom could optimize its management and get high efficiency.

- While setting up a modern corporation system, China Telecom will take some effective forms of capital constitution, such as share holding system. This will not only give China Telecom a better chance to get finance support from the capital market, but also help it begin its way of capital operation towards the international trend.

We are quite confident that with the system reform and the efforts that China Telecom will make to improve its service quality and customer satisfaction, China Telecom will definitely perform itself successfully and have a bright future.

\section{References}

[1] Zhu Younong and $\mathrm{Li}$ Guoliang. Economics of Posts \& Telecommunications. Beijing: China Economy Publishing House, 1994.

[2] China Posts and Telecommunications 1996 Annual Report. Beijing: MPT, 1997.

[3] China Posts and Telecommunications 1997 Annual Report. Beijing: MII, 1998.

[4] Yu Hui. Regulation System of China's Government. Reform. No.3, pp93-103, 1998.

[5] Zeng Hongjian. Study on the operational mechanism of China's telecommunication enterprises. Proceedings of the Seminar of the Developing Strategy and Management of Communications, Cheng Du, 1995. 